\title{
BRAZILIAN PIONEERING IN IMMERSIVE AUDIO: PRACTICAL EXPERIENCES
}

Chair: Rafael de Castro - Regional Director, Latin America Dolby Laboratories Co-chair: Luana Carolina Bravo - Educational committee - SET

The focus of this panel will be to show how immersive audio production works in practice, from a broadcast point of view. We will take as examples the Rock In Rio 2015 which was the first live event made in 4k in the world, we will also address the Carnival of this year that was again pioneer in Atmos OTT broadcasting, besides live events we will also treat post-production tools. As an Introduction we will have a brief explanation about immersive audio status in the world.

- Speaker: Carlos Watanabe - Director for Emerging Markets at Dolby Laboratories

- IMMERSIVE AUDIO IN PAY TV Speaker: Gabriel Thomazini - Globosat Audio Coordinator With Immersive Audio being presented as a desired option in 4K broadcasts, this presentation will address the characteristics of using the Dolby ATMOS format in the Broadcast chain, sharing the impressions and challenges of this technology in Pay-TV.

- DOLBY ATMOS AT RIO CARNIVAL Speaker: Carlos B. Ronconi - Assessor Técnico - Grupo Globo

First worldwide broadcast with remote mix using Dolby Atmos. More than 40 channels canalized from the Sambódromo to the Globo studios in Jacarepaguá, mixed with Dolby Atmos technology.

- IMMERSIVE AUDIO IN DRAMA

Speaker: Rodrigo Meirelles - Sound Supervisor - TV Globo

Among the experiences recently performed by Globe TV in Dolby Atmos, dramaturgy is a highlight. Experimental mixes of clips from TV series directed to Dolby Atmos Home were the first performed in Latin America. Get from a single mix to generate an immersive experience to a large number of 
viewers promotes a change of scenery in the sound for TV that we have not seen since the implementation of the stereo. The purpose of this presentation is to discuss creative opportunities and impacts on workflows that the technology imposes on drama, from soap-opera to tv series, in the context of multiple platforms and the consumption of immersive content in soundbars and headphones.

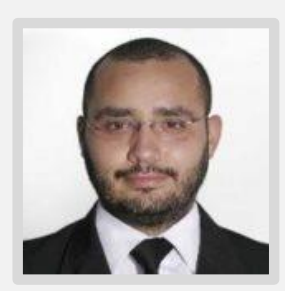

\section{Rafael de Castro - Regional Director, Latin America Dolby Laboratories}

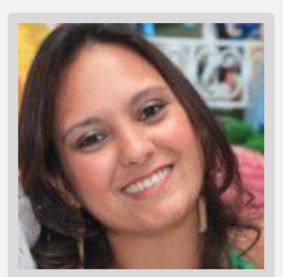

\section{Luana Carolina Bravo - Educational committee - SET}

Electrician engineer with emphasis in electronics from the Faculty of Engineering São Paulo. Post graduate in Digital TV by Mackenzie University. She has been in the television business for over 10 years. Participant in the SET board since 2012, member of the Technical Reception Group (GTRx) of GIRED, member of the Market Module of the Brazilian Digital TV Forum and representative of ABERT in the Project UHD- Brazil

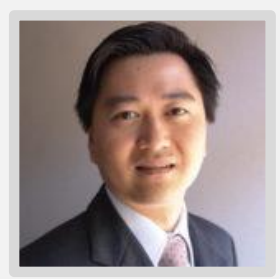

\section{Carlos Watanabe - Director for Emerging Markets at Dolby Laboratories Carlos Watanabe}

is Director for Emerging Markets at Dolby Laboratories, the global leader in audiovisual entertainment technologies. For more than 50 years, Dolby has created audio, video and voice technologies that transform entertainment and communications on mobile devices, movies, the home and work.Carlos is an Electrical Engineer graduated from the State University of Campinas (UNICAMP), with an MBA from the Ross School of Business at the University of Michigan. He has more than 20 years of experience in technology, media and entertainment companies, and senior management consulting.

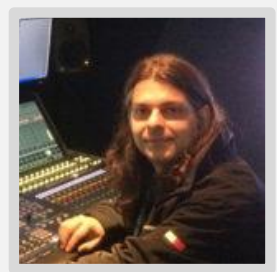

\section{Gabriel Thomazini - Globosat Audio Coordinator}

Working for over 30 years with professional audio, he was a recording technician and music content mixer, P.A and Sound Designer technician. For more than 15 years in the broadcast area, he has participated in projects for the audio infrastructure of major events such as Olympics Games, World Cups and International Shows. Participated in the development of mobile units, television studios and IP infrastructure projects for professional audio and automation systems. Member of AES since 1998, holds lectures and workshops promoting new techniques and technologies for audio production He is currently the Audio Coordinator for Globosat, considered the largest cable TV programmer in Latin America. 


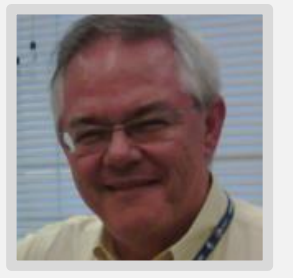

\section{Carlos B. Ronconi - Assessor Técnico - Grupo Globo}

Technical Advisor at Globo Studios where he works in the audio area.He participated in the deployment of various audio technologies for live and sound post production, from the first audio workstation to the Mobile Audio Unit. Coordinates the audio of events and broadcasts of Entertainment such as Carnival, Roberto Carlos Special, Child Hope, Rock In Rio, Brazilian Day, etc. Graduated in Cinema from Gama Filho University and studied Electrical Engineering at the Fundação Valeparaibana de Ensino, São José dos Campos, SP. Graduated in Music (Classical Piano) by the Santa Cecilia Conservatory, also of SJC. He also worked at the Instituto de Atividades Espaciais, Transamérica Studios and Som Livre.

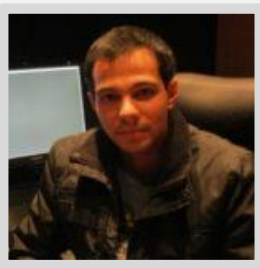

\section{Rodrigo Meirelles - Sound Supervisor - TV Globo}

Rodrigo Meirelles is Executive Supervisor of Audio of Globo. He holds a degree in Electronic Engineering and Computing, Recording and Phonographic Production and has a Masters in Education and Media. For 16 years in the audio market, he began his career as an engineer in music production studios in Rio de Janeiro, in maintenance, installation and projects of audio recording studios, he was an instructor and founder of the ProClass training center, a pioneer in official certifications In Pro Tools and Avid in Brazil, and in TV Globo, was responsible for the area of post-production from 2009 to 2014. Today he is responsible for the Entertainment Audio Production area (Estúdios Globo). He was a university professor for 8 years teaching courses in Phonographic Production, Audiovisual Production, Radio and TV and Graduation in Cinema. 